\title{
Nitrous Oxide Emissions from Soils with Different Vertical Soil Moisture Distribution Patterns
}

\author{
Qi Wei ${ }^{1,2}$, Junzeng Xu' ${ }^{1,2 *}$, Shihong Yang ${ }^{1,2}$, Yan $\mathrm{Ma}^{2}$, Twecan Dalson ${ }^{2}$ \\ ${ }^{1}$ State Key Laboratory of Hydrology-Water Resources and Hydraulic Engineering, Hohai University, \\ Nanjing 210098, China \\ ${ }^{2}$ College of Water Conservancy and Hydropower Engineering, Hohai University, Nanjing 210098, China
}

Received: 30 June 2016

Accepted: 18 July 2016

\begin{abstract}
To reveal the impact of vertical non-uniform distribution of soil moisture on nitrous oxide $\left(\mathrm{N}_{2} \mathrm{O}\right)$ emissions, incubated experiments were conducted from April to August 2013 on silty clay and sandy loam with four watering regimes [surface watering (SW) and subsurface watering application to levels 12, 15, and $18 \mathrm{~cm}$ below soil surface (SUW12, SUW15, SUW18)]. Short-term pulse emissions of $\mathrm{N}_{2} \mathrm{O}$ from both soils during the drying process were observed. The soil water-filled pore space (WFPS) at 0-12 cm depths for peak $\mathrm{N}_{2} \mathrm{O}$ fluxes in SW and SUW soils fell within 34-66\%, 22-72\%, 25-35\%, and 19-39\% for silty clay and sandy loam, respectively. Our results also suggest that the $\mathrm{N}_{2} \mathrm{O}$ fluxes from soil of sily clay with higher $\mathrm{N}$ content are much higher than that from sandy loam, and $\mathrm{N}_{2} \mathrm{O}$ were more easily influenced by soil moisture in SW soils than in SUW soils. However, more research is needed to identify an ideal soil-wetting pattern and the way to realize the ideal soil-wetting pattern, especially on soil with plant growth and fertilization.
\end{abstract}

Keywords: nitrous oxide, soil moisture, non-uniform distribution, watering method, water-filled porosity

\section{Introduction}

Global warming induced by increasing greenhouse gas concentrations in the atmosphere is a matter of great environmental concern. Nitrous oxide $\left(\mathrm{N}_{2} \mathrm{O}\right)$ is an important long-living greenhouse gas that has attracted considerable attention during the past few decades because of its contribution to global warming and ozone depletion [1-3]. Agriculture accounts for approximately $60 \%$ of global anthropogenic $\mathrm{N}_{2} \mathrm{O}$ emissions [1, 4], and agricultural $\mathrm{N}_{2} \mathrm{O}$ emissions are projected to increase by $35 \%$ to $60 \%$ by 2030 because of increased chemical and manure nitrogen $(\mathrm{N})$ inputs [5].

*e-mail: xjz481@hhu.edu.cn
Water management has been recognized as one of the most important practices affecting $\mathrm{N}_{2} \mathrm{O}$ emissions [6-7]. Many researchers have found that peak $\mathrm{N}_{2} \mathrm{O}$ emissions were observed during the drying period after soil watering, caused either by precipitation or irrigation. For instance, Ding [8] found that rainfall and irrigation typically enhance soil $\mathrm{N}_{2} \mathrm{O}$ peak emissions from maize-wheat rotation soils. Yao et al. [9] showed that pulse emissions of $\mathrm{N}_{2} \mathrm{O}$ occurred during repeated drying and wetting cycles in rice-wheat rotation systems. Peng et al. [10] reported that maximum $\mathrm{N}_{2} \mathrm{O}$ emissions were measured eight days after irrigation and applying base fertilizer in winter wheat croplands.

In addition, some previous studies have confirmed that the peak $\mathrm{N}_{2} \mathrm{O}$ emissions can be observed in a specific water-filled pore space (WFPS) range. In a field trial, 
Hansen et al. [11] observed the highest $\mathrm{N}_{2} \mathrm{O}$ emissions within a WFPS range of $45-75 \%$. Khalil and Baggs [12] detected peak $\mathrm{N}_{2} \mathrm{O}$ flux from brown earth silt loam at $75 \%$ WFPS in a laboratory experiment. Similarly, a laboratory incubation experiment conducted by Sey et al. [13] revealed that pulse $\mathrm{N}_{2} \mathrm{O}$ emission was observed from a cultivated sandy-loam soil at $80 \%$ WFPS. Ding et al. [14] reported that the optimum WFPS for peak $\mathrm{N}_{2} \mathrm{O}$ flux in aquic inceptisol (a calcareous, fluvo-aquic sandy loam) was 50\% (ranging 45-60\%) in northern China. However, all the above-mentioned literature mainly focused on the impact of the soil-drying process or soil moisture content on $\mathrm{N}_{2} \mathrm{O}$ emissions [2, 9, 15-19], with very little attention paid to the influence of soil moisture distribution (either horizontal or vertical) characteristics on $\mathrm{N}_{2} \mathrm{O}$ emissions. In the agricultural farmland ecosystem, the subsurface irrigation as a typical water-saving irrigation (WSI) practice is often used in many countries, and results in moisture redistribution and non-uniform soil wetting patterns $[17,20]$. In the natural ecosystem of the Hydro-Fluctuation Belt, frequent variation of shallow groundwater levels usually also causes soil moisture nonuniform distribution. The moisture vertical non-uniform characteristics may lead to variations in soil $\mathrm{N}_{2} \mathrm{O}$ emission patterns; however, no studies have examined the effects of non-uniform distribution of soil moisture on $\mathrm{N}_{2} \mathrm{O}$ emissions.

Therefore, assuming that soil moisture vertical distribution characteristics under different irrigation regimes have a great influence on the $\mathrm{N}_{2} \mathrm{O}$ emission patterns from soils with different textures, $\mathrm{N}_{2} \mathrm{O}$ from two typical soils with four different vertical wetting patterns [surface watering (SW) and subsurface watering (SUW) application to levels 12,15 , and $18 \mathrm{~cm}$ below soil surface (SUW12, SUW15, SUW18)] were measured in current research to quantify $\mathrm{N}_{2} \mathrm{O}$ emissions and investigate the impact of soil moisture distribution patterns on soil $\mathrm{N}_{2} \mathrm{O}$ emissions.

\section{Materials and Methods}

\section{Experiment Design and Sampling}

To investigate the impacts of the soil moisture vertical distribution patterns, realized either by surface watering (SW) and subsurface watering (SUW) on soil $\mathrm{N}_{2} \mathrm{O}$ emissions, incubated experiments were conducted on a silty clay and sandy loam soil from April to August 2013 in Nanjing, China. Detailed information about both soils can be found in another document [21]. The soils were air-dried, ground using a hammer mill, and sieved and homogenized before being packed into soil boxes $(40 \times 40 \times 60 \mathrm{~cm})$ at the bulk density of $1.25 \mathrm{~g} \mathrm{~cm}^{-3}$ for the $0-10 \mathrm{~cm}$ surface depths and $1.33 \mathrm{~g} \mathrm{~cm}^{-3}$ for the $10-50 \mathrm{~cm}$ depths. These soil mesocosms were placed randomized during the experiment, and were stored under a shelter that was closed on rainy days to avoid the influence of rainfall. For SW treatment, water was applied to the soil surface to replenish the soil moisture to field capacity at $0-50 \mathrm{~cm}$ deep. For SUW treatments, water was supplied from the osmotic pipe connected to a Marriott bottle to saturate the subsoil at the 12-50, 15-50, and 18-50 cm depths (SUW12, SUW15, and SUW18). The water was applied twice, with the first at 20:00 h on April 18 and 21 for silty clay and sandy loam, and the second at 20:00 h on June 12 and 14.

During the experiment, the gas samples were collected from each of the three replicated soil boxes using the static chamber method at 10-minute intervals between 9:45 h and 10:15 h on each sampling day. $\mathrm{N}_{2} \mathrm{O}$ concentrations in the gas samples were analyzed by an Agilent 7890A gas chromatograph system equipped with an electron capture detector (ECD). Fluxes of $\mathrm{N}_{2} \mathrm{O}$ were calculated according to the linear increase rate of $\mathrm{N}_{2} \mathrm{O}$ concentration within the chamber [10], and the temperatures inside the chamber. Soil samples (approximately 2-3 g each) from the upper layer of 0 to $24 \mathrm{~cm}$ soils (every $4 \mathrm{~cm}$ vertically) were collected through $20 \mathrm{~mm}$ holes in the soil mesocosm (Fig. 1) using

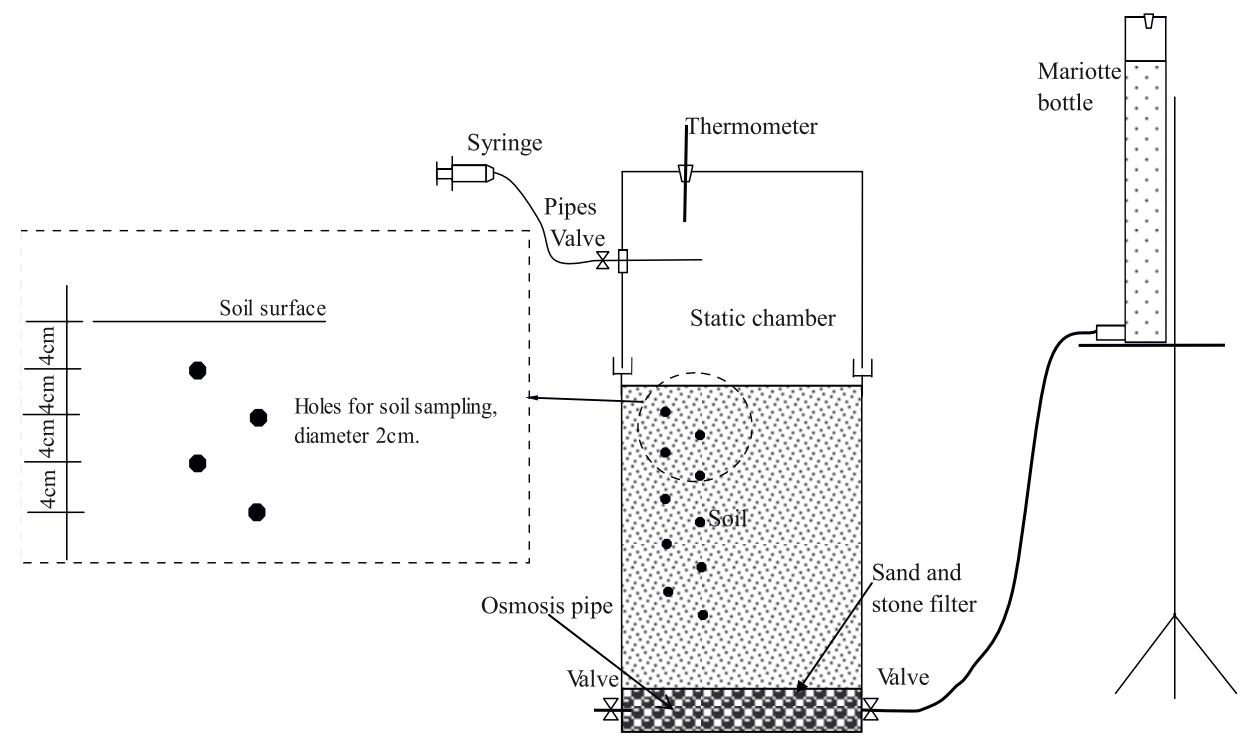

Figu. 1. Schematic diagram of the experiment. 


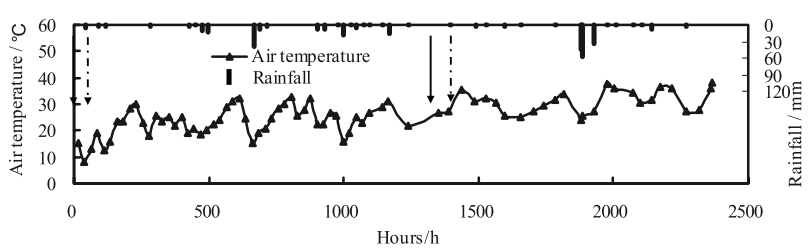

Fig. 2. Weather conditions during the experimental period (first and second observation periods of silty clay and sandy loam) in Nanjing, Jiangsu, China. (Note that the solid and dotted arrows represent the watering times of silty clay and sandy loam, respectively).

stainless samplers. Water-filled pore space (WFPS) was calculated as the percentage of soil volumetric moisture content to soil porosity $[14,22]$.

\section{Statistical Analysis}

Statistical analyses were performed using Microsoft Office 2003 (Microsoft, Redmond, Washington, USA) and SPSS19.0 (SPSS Inc., Chicago, USA). The paired t-test was performed to detect the difference in $\mathrm{N}_{2} \mathrm{O}$ fluxes between SW and SUW treatments at certain observation times. Correlation analysis was performed to investigate the influence of soil moisture and air temperature on $\mathrm{N}_{2} \mathrm{O}$ fluxes. For all the statistical analyses, $\mathrm{p} \leq 0.05$ and $\mathrm{p} \leq 0.01$ levels were considered to be significant and highly significant [9].

\section{Results}

\section{Air Temperature and Precipitation}

During the experimental period, rainfall occurred 18 and 8 times, and 17 and 7 times during the first and second observation stages of silty clay and sandy loam, respectively (Fig. 2). Total rainfall values during the

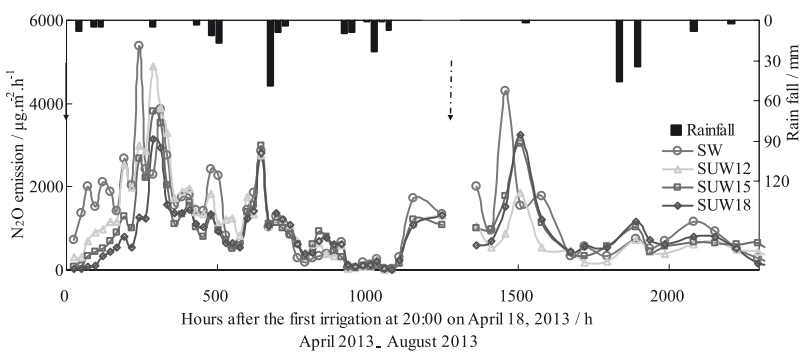

Fig. 3. $\mathrm{N}_{2} \mathrm{O}$ fluxes from silty clay under different soil moisture conditions. (Note that the solid and dotted arrows represent the watering times of silty clay and sandy loam, respectively).

incubation of silty clay and sandy loam were $226 \mathrm{~mm}$ and $203 \mathrm{~mm}$, respectively, of which 59\% (133 mm) and 68\% $(138 \mathrm{~mm})$ occurred in the period between the two water applications. Air temperatures of silty clay and sandy loam ranged from $8.3^{\circ} \mathrm{C}$ to $37.9^{\circ} \mathrm{C}$ and from $15.3^{\circ} \mathrm{C}$ to $38.1^{\circ} \mathrm{C}$, with averages of $24.9^{\circ} \mathrm{C}$ and $26.1^{\circ} \mathrm{C}$, respectively, at 10:00 h.

\section{$\mathrm{N}_{2} \mathrm{O}$ Emissions Flux \\ $\mathrm{N}_{2} \mathrm{O}$ fluxes from Silty Clay}

$\mathrm{N}_{2} \mathrm{O}$ emissions from silty clay increased rapidly at the beginning ( 0 to $288 \mathrm{~h}$ and 0 to $162 \mathrm{~h}$ after the first and second waterings, respectively) of the experimental period, as shown in Fig. 3. In the case of SW treatment, the maximum $\mathrm{N}_{2} \mathrm{O}$ fluxes are 5,370.2 and 4,305.2 $\mu \mathrm{g}$ $\mathrm{N}_{2} \mathrm{O} \mathrm{m}^{-2} \mathrm{~h}^{-1}$ observed $241 \mathrm{~h}$ and $114 \mathrm{~h}$ after the first and second waterings, respectively. $\mathrm{N}_{2} \mathrm{O}$ emissions from SUW treatments followed a similar pattern, with peak fluxes of 4,898.3, 3,813.2, and 3,147.0 $\mu \mathrm{g} \mathrm{N}_{2} \mathrm{O} \mathrm{m} \mathrm{m}^{-2} \mathrm{~h}^{-1}$, and $1,857.6,3,035.1$, and 3,232.0 $\mu \mathrm{g} \mathrm{N} \mathrm{N}_{2} \mathrm{~m}^{-2} \mathrm{~h}^{-1}$ for SUW12, SUW15, and SUW18 treatments after the first and second waterings, respectively. The peak fluxes of $\mathrm{N}_{2} \mathrm{O}$ from SUW soils appeared $47 \mathrm{~h}$ and $48 \mathrm{~h}$ later than

Table 1. Average $\mathrm{N}_{2} \mathrm{O}$ emissions from different soils at different observation stages.

\begin{tabular}{|c|c|c|c|c|c|}
\hline \multirow{3}{*}{ Soil Texture } & \multicolumn{5}{|c|}{$\mathrm{N}_{2} \mathrm{O}$ emission values $/ \mu \mathrm{g} \mathrm{N} \mathrm{O} \mathrm{m}^{-2} \mathrm{~h}^{-1}$} \\
\cline { 2 - 6 } & Observation stage & $\mathrm{SW}$ & $\mathrm{SUW} 12$ & $\mathrm{SUW} 15$ & $\mathrm{SUW} 18$ \\
\hline \multirow{4}{*}{ Silty clay } & $0 \mathrm{~h}-288 \mathrm{~h}$ & $2,152.2 \pm 330.4 \mathrm{a}$ & $1,727.2 \pm 395.3 \mathrm{a}$ & $1,169.0 \pm 334.2 \mathrm{~b}$ & $710.2 \pm 254.6 \mathrm{c}$ \\
\cline { 2 - 6 } & $288 \mathrm{~h}-1104 \mathrm{~h}$ & $1,042.3 \pm 165.6 \mathrm{a}$ & $1,072.5 \pm 160.5 \mathrm{a}$ & $891.3 \pm 137.0 \mathrm{bc}$ & $886.4 \pm 119.7 \mathrm{c}$ \\
\cline { 2 - 6 } & $1,362 \mathrm{~h}-1,506 \mathrm{~h}$ & $2,200.7 \pm 735.0 \mathrm{a}$ & $1,078.6 \pm 279.8 \mathrm{a}$ & $1,696.0 \pm 482.0 \mathrm{a}$ & $1,511.8 \pm 609.6 \mathrm{a}$ \\
\cline { 2 - 6 } & $1,506 \mathrm{~h}-2,370 \mathrm{~h}$ & $663.7 \pm 132.7 \mathrm{a}$ & $444.3 \pm 54.5 \mathrm{~b}$ & $607.7 \pm 74.5 \mathrm{a}$ & $637.9 \pm 47.1 \mathrm{a}$ \\
\cline { 2 - 6 } & $0 \mathrm{~h}-2,370 \mathrm{~h}$ & $1,267.0 \pm 134.7 \mathrm{a}$ & $1,082.2 \pm 122.8 \mathrm{a}$ & $948.2 \pm 104.1 \mathrm{~b}$ & $855.55 \pm 90.6 \mathrm{c}$ \\
\hline \multirow{5}{*}{ Sandy loam } & $0 \mathrm{~h}-239 \mathrm{~h}$ & $47.6 \pm 11.5 \mathrm{a}$ & $30.7 \pm 8.3 \mathrm{abc}$ & $22.9 \pm 4.1 \mathrm{bc}$ & $23.4 \pm 6.6 \mathrm{c}$ \\
\cline { 2 - 6 } & $239 \mathrm{~h}-1,176 \mathrm{~h}$ & $21.7 \pm 2.2 \mathrm{a}$ & $14.7 \pm 1.7 \mathrm{~b}$ & $11.58 \pm 1.2 \mathrm{~cd}$ & $9.78 \pm 1.5 \mathrm{~d}$ \\
\cline { 2 - 6 } & $1,312 \mathrm{~h}-1,576 \mathrm{~h}$ & $78.7 \pm 21.6 \mathrm{a}$ & $44.0 \pm 13.6 \mathrm{bcd}$ & $34.1 \pm 9.8 \mathrm{acd}$ & $31.7 \pm 13.4 \mathrm{ad}$ \\
\cline { 2 - 6 } & $1,576 \mathrm{~h}-2,297 \mathrm{~h}$ & $22.5 \pm 5.3 \mathrm{a}$ & $17.0 \pm 6.0 \mathrm{a}$ & $13.9 \pm 3.5 \mathrm{a}$ & $12.2 \pm 2.5 \mathrm{a}$ \\
\cline { 2 - 6 } & $0 \mathrm{~h}-2,297 \mathrm{~h}$ & $30.2 \pm 3.8 \mathrm{a}$ & $19.8 \pm 2.5 \mathrm{~b}$ & $15.5 \pm 1.7 \mathrm{~cd}$ & $13.9 \pm 2.0 \mathrm{~d}$ \\
\hline
\end{tabular}

Statistical analyses were performed using the paired t-test. Different letters a, b, and $\mathrm{c}$ in each row represent significant differences between the treatments at the $\mathrm{p}=0.05$ level. 
those from SW soil after the first and second waterings, respectively. That is probably because the wetting body and the soil water depleted rate in SUW soils was smaller than in SW soil, which might not easily affect the surface soil microorganisms, soil gas permeability, and other external environmental factors, and slow down the soil microbial activities responsible for GHG emissions [17, 23]. Thereafter, $\mathrm{N}_{2} \mathrm{O}$ emissions declined gradually for all the treatments, though several subpeaks of $\mathrm{N}_{2} \mathrm{O}$ fluxes appeared in the late observation period. $\mathrm{N}_{2} \mathrm{O}$ fluxes were primarily within the range of 0 to $1,000 \mu \mathrm{g} \mathrm{N} \mathrm{N}_{2} \mathrm{O} \mathrm{m}^{-2} \mathrm{~h}^{-1}$ during this period with the minimum values of 33.6, 9.2, 27.0, and $6.2 \mu \mathrm{g} \mathrm{N} \mathrm{N}_{2} \mathrm{O} \mathrm{m}^{-2} \mathrm{~h}^{-1}$ observed in the period of $1,057-1,080 \mathrm{~h}$ after the first watering and 106.4, 165.2, 245.9, and $196.7 \mu \mathrm{g} \mathrm{N} \mathrm{N}_{2} \mathrm{~m}^{-2} \mathrm{~h}^{-1}$ observed 1,026 h after the second watering for SW, SUW12, SUW15, and SUW18 soils, respectively. The cumulative $\mathrm{N}_{2} \mathrm{O}$ fluxes from SUW12, SUW15, and SUW18 soils were 15.4\%, $19.2 \%$, and $23.1 \%$ lower than those from SW soil after the two waterings, with the cumulative fluxes from SUW18 as the least in both soils. This implies that the moisture distribution patterns under SUW soils could be effective for mitigating $\mathrm{N}_{2} \mathrm{O}$ emissions.

Generally, $\mathrm{N}_{2} \mathrm{O}$ fluxes from silty clay were in the order of $\mathrm{SW}>\mathrm{SUW} 12>\mathrm{SUW} 15>\mathrm{SUW} 18$ with the fluxes from SW and SUW12 soils being significantly higher than those from SUW15 and SUW18 soils (Table 1), among which the average $\mathrm{N}_{2} \mathrm{O}$ fluxes from SUW15 and SUW18 soils were significantly lower than that from SW and SUW12 soils during the period of 0 to $1,104 \mathrm{~h}$ after the first watering, and the average $\mathrm{N}_{2} \mathrm{O}$ flux from SUW12 treatment was significantly lower than those from other treatments 1,506 to $2,370 \mathrm{~h}$ after the first watering. However, no significant difference was observed in $\mathrm{N}_{2} \mathrm{O}$ fluxes from the different treatments during the pulse emission period (1,362-1,506 $\mathrm{h})$ after the initial watering.

\section{$\mathrm{N}_{2} \mathrm{O}$ fluxes from Sandy Loam}

$\mathrm{N}_{2} \mathrm{O}$ emissions from sandy loam varied in the similar pattern to those from silty clay among different watering treatments, although the flux values were significantly different (Figs 3-4). The $\mathrm{N}_{2} \mathrm{O}$ fluxes increased rapidly from 0 to $239 \mathrm{~h}$ and 0 to $162 \mathrm{~h}$ after the first and second waterings, respectively. For SW soil, the peak fluxes were

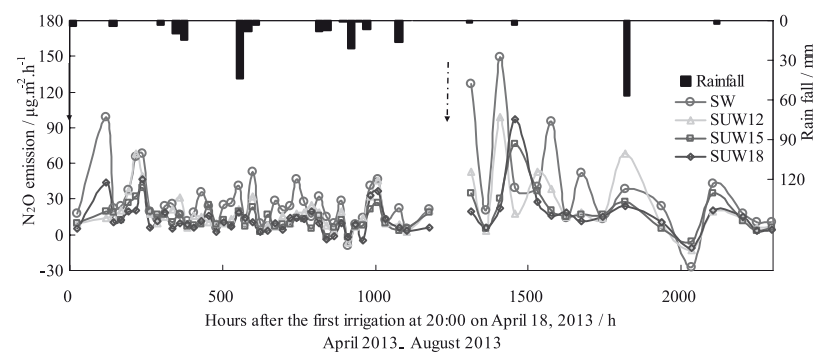

Fig. 4. $\mathrm{N}_{2} \mathrm{O}$ fluxes from sandy loam under different soil moisture conditions. (Note that the solid and dotted arrows represent the watering times of silty clay and sandy loam, respectively).
98.5 and $126.7 \mu \mathrm{g} \mathrm{N}_{2} \mathrm{O} \mathrm{m} \mathrm{m}^{-2} \mathrm{~h}^{-1}$ observed $119 \mathrm{~h}$ and $114 \mathrm{~h}$ after the first and second waterings, respectively. For SUW soils, the pulse $\mathrm{N}_{2} \mathrm{O}$ fluxes primarily ranged from 40 to $100 \mu \mathrm{g} \mathrm{N} \mathrm{O} \mathrm{m}^{-2} \mathrm{~h}^{-1}$, and the maximum $\mathrm{N}_{2} \mathrm{O}$ fluxes were 68.6, 39.7, and $46.5 \mu \mathrm{g} \mathrm{N}_{2} \mathrm{O} \mathrm{m}^{-2} \mathrm{~h}^{-1}$ and 98.7, 76.6, and $96.9 \mu \mathrm{g} \mathrm{N}_{2} \mathrm{O} \mathrm{m}^{-2} \mathrm{~h}^{-1}$ for SUW12, SUW15, and SUW18 soils after the first and second waterings, respectively. On the whole, the pulse fluxes were observed 48-120 h later from SUW soils than from SW soil after the two waterings. Since then, $\mathrm{N}_{2} \mathrm{O}$ fluxes for all treatments were reduced gradually and mainly ranged from -30 to $10 \mu \mathrm{g} \mathrm{N}_{2} \mathrm{O} \mathrm{m} \mathrm{m}^{-2}$ $\mathrm{h}^{-1}$ during the period of 239-1,176 h, and 162-1,002 $\mathrm{h}$ after the first and second waterings, respectively. The minimum $\mathrm{N}_{2} \mathrm{O}$ fluxes from SW, SUW12, SUW15, and SUW18 soils were $-9.4,-6.4,-2.3$, and $-5.2 \mu \mathrm{g} \mathrm{N}_{2} \mathrm{O} \mathrm{m}^{-2} \mathrm{~h}^{-1}$; and -27.7, $-13.1,-5.3$, and $-11.0 \mu \mathrm{g} \mathrm{N}_{2} \mathrm{O} \mathrm{m}^{-2} \mathrm{~h}^{-1}$ observed at 911-959 $\mathrm{h}$ and $738 \mathrm{~h}$ after the first and second waterings, respectively. These negative fluxes usually appeared under the low soil moisture conditions in current research, possibly due to the low availability of soil nitrogen owing to the slow mineralization of organic matter [10, 24-25]. Generally, the cumulative $\mathrm{N}_{2} \mathrm{O}$ emission fluxes from SUW12, SUW15, and SUW18 soils were $34.4 \%, 48.7 \%$, and $54.0 \%$ lower than those from SW soil after two waterings.

For sandy loam, the average $\mathrm{N}_{2} \mathrm{O}$ flux was significantly higher in SW soil than in SUW soils (Table 1), and $\mathrm{N}_{2} \mathrm{O}$ fluxes from different treatments were in the order of SW $>$ SUW12 $>$ SUW15 $>$ SUW18, among which fluxes from SUW soils were significantly lower than those from the SW soils except during the period of 1,576-2,297 h after the first wetting. For example, the average $\mathrm{N}_{2} \mathrm{O}$ flux from SW soil was significantly higher than those from SUW15 and SUW18 soils between $0 \mathrm{~h}$ and $239 \mathrm{~h}$, and higher than those from all the three SUW soils during 239-1,176 h, and those from SUW12 soils during 1,312-1,576 $\mathrm{h}$ after the first wetting.

\section{The Impact of Soil Moisture Distribution Patterns on $\mathrm{N}_{2} \mathrm{O}$ Emissions}

Soil moisture is one of the most sensitive factors to soil $\mathrm{N}_{2} \mathrm{O}$ fluxes [26-28]. The vertical profiles of soil moisture for SW and SUW treatments from silty clay are plotted in Fig. 5. Soil moisture varied greatly at depths of $0-12 \mathrm{~cm}$ in all treatments, while they varied a little in soil beneath the depth of $12 \mathrm{~cm}$ from 96-288 h after each wetting. Soil moisture decreased greatly in topsoils and increased slightly in deep soils due to the infiltration and evaporation process. For SW soil, the WFPS in the top $0-12 \mathrm{~cm}$ soils decreased from $72.2-79.7 \%$ to $42.3-66.8 \%$ during $0-288 \mathrm{~h}$ after the first watering. The corresponding $\mathrm{N}_{2} \mathrm{O}$ fluxes increased with the decrease in soil moisture, and the peak $\mathrm{N}_{2} \mathrm{O}$ flux of 5,370.2 $\mu \mathrm{g} \mathrm{N}_{2} \mathrm{O} \mathrm{m}^{-2} \mathrm{~h}^{-1}$ observed at $241 \mathrm{~h}$ when the top WFPS in $0-12 \mathrm{~cm}$ soil fell within the ranges of $44-66 \%$. Then the WFPS in the top $0-12 \mathrm{~cm}$ soils decreased gradually to $20.5-56.6 \%$ during $288-1,104 \mathrm{~h}$, and $\mathrm{N}_{2} \mathrm{O}$ fluxes were reduced with the decrease in soil moisture. However, the second watering-drying process incurred short-term pulse $\mathrm{N}_{2} \mathrm{O}$ emissions with fluxes increased 


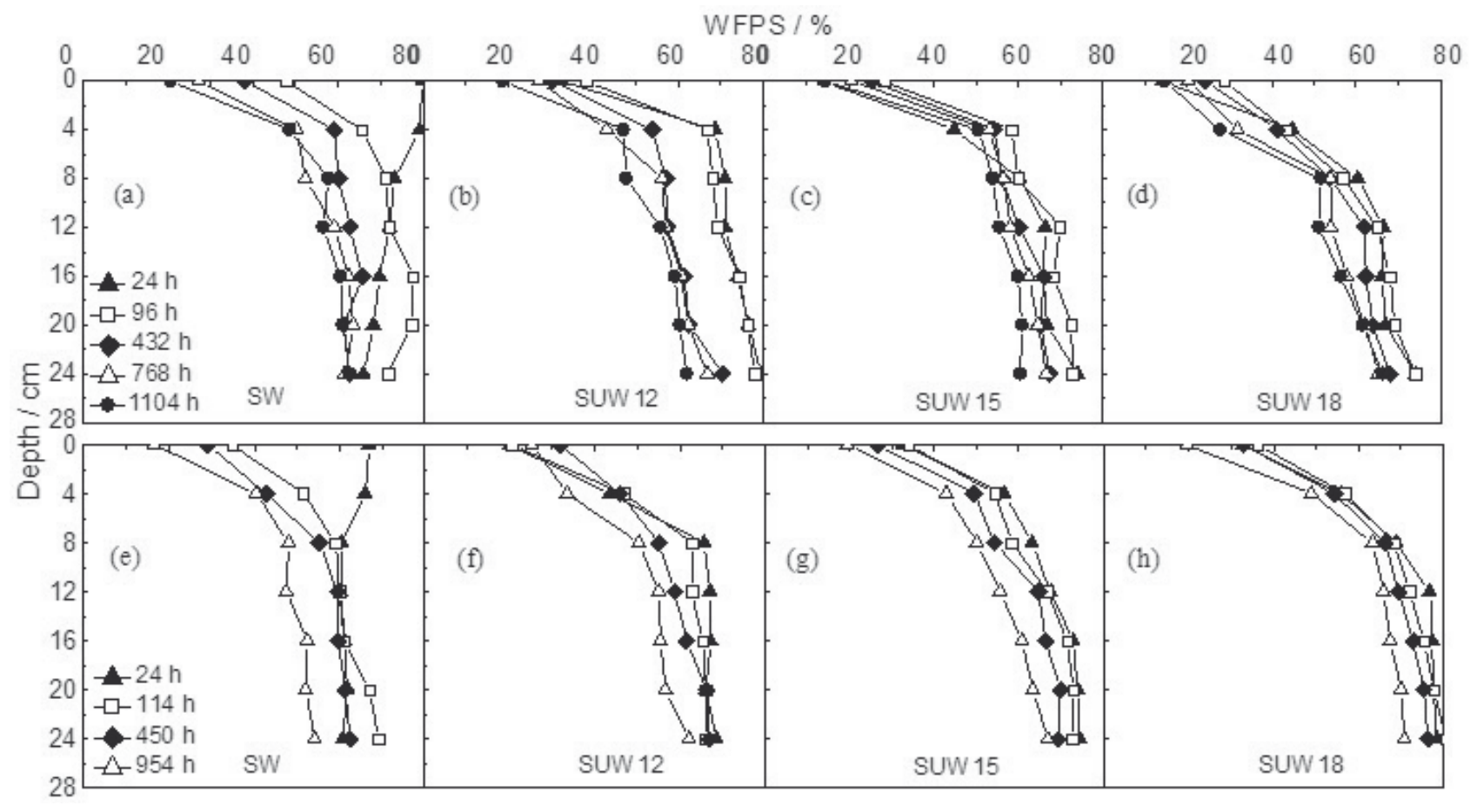

Fig. 5. Vertical soil moisture profiles of silty clay under different water treatments.

rapidly to 2,015.6 $\mu \mathrm{g} \mathrm{N}_{2} \mathrm{O} \mathrm{m} \mathrm{m}^{-2} \mathrm{~h}^{-1}$ within $0-18 \mathrm{~h}$ after the second watering (1,344-1,362 $\mathrm{h}$ after the initial watering), which increased by $549.4 \%$ over those observed at $1,104 \mathrm{~h}$ after the initial wetting. For SUW soils, the soil moisture increased initially and then was reduced in the top $0-12 \mathrm{~cm}$ soil after each watering because of infiltration and evaporation processes. The corresponding $\mathrm{N}_{2} \mathrm{O}$ fluxes first increased then decreased with the decrease in soil moisture after the wettings, and the highest $\mathrm{N}_{2} \mathrm{O}$ fluxes of 4,898.3, 3,813.2, and 3,147.0 $\mu \mathrm{g} \mathrm{N}_{2} \mathrm{O} \mathrm{m} \mathrm{m}^{-2} \mathrm{~h}^{-1}$ were observed at 241-288 $\mathrm{h}$ under the SUW12, SUW15, and SUW18 treatments when the WFPS in the top $0-12 \mathrm{~cm}$ soil mainly fell within the ranges of 34-62\%, 27-64\%, and $25-63 \%$, respectively.

Generally, $\mathrm{N}_{2} \mathrm{O}$ fluxes from silty clay after the first watering were correlated with the WFPS in the top 0-12 $\mathrm{cm}(\mathrm{SW})$ soils at $\mathrm{p}<0.01$ significance level, and correlated to the WFPS in 8-12 cm (SUW12), 4-12 cm (SUW15), and $8-12 \mathrm{~cm}$ (SUW18) soils at the $\mathrm{p}<0.05$ significance level (Table 2). However, after the second watering, a significant correlation was found between $\mathrm{N}_{2} \mathrm{O}$ fluxes and the WFPS values in the top 0-8 cm (SW), 8-12 cm (SUW12 and SUW15), and 4-12 cm (SUW18) soils $(\mathrm{p} \leq 0.05)$. As a whole, the correlation between $\mathrm{N}_{2} \mathrm{O}$ fluxes and the WFPS in 0-12 cm soils was typically higher in SW soil than in SUW soils. The results also indicated that $\mathrm{N}_{2} \mathrm{O}$ fluxes from silty clay were more easily influenced by soil moisture in SW treatment than in SUW treatments. Moreover, the most significant correlations were found between $\mathrm{N}_{2} \mathrm{O}$ fluxes and the WFPS values at $8 \mathrm{~cm}(\mathrm{SW})$ $(\mathrm{p}<0.01)$ and $12 \mathrm{~cm}$ (SUW12, SUW15 and SUW18) soils $(p<0.05)$ after the first watering, and the WFPS values at $4 \mathrm{~cm}(\mathrm{SW})$ soil, $8 \mathrm{~cm}(\mathrm{SUW} 12)$ soil, and $12 \mathrm{~cm}$ (SUW15 and SUW18) soils $(\mathrm{p}<0.05)$ after the second watering. The WFPSs, which are significantly correlated to $\mathrm{N}_{2} \mathrm{O}$ fluxes, usually are presented in a shallower soil depth in SW than in SUW soils, and the WFPS values possibly fell within the ranges of $40.6-79.3 \%, 50.4-71.0 \%, 55.6-71.2 \%$, and $51.2-70.9 \%$ for SW, SUW12, SUW15, and SUW18 soils, respectively.

The soil moisture in the top $0-12 \mathrm{~cm}$ soil of sandy loam varied in a similar pattern to that from silty clay, although the ranges of moistures in sandy loam (8-41\% WFPS) were much lower than those in silty clay (14-80\% WFPS). The WFPS in the top $0-12 \mathrm{~cm}$ soils varied significantly in both SW and SUW treatments. In SW soil, the WFPS was reduced from $31.0-37.6 \%$ to $7.9-26.3 \%$ at $0-12 \mathrm{~cm}$ depths during 0 to $1,176 \mathrm{~h}$ (Fig. 6), whereas the WFPS in SUW12, SUW15, and SUW18 soils initially increased from 25.4$40.8 \%, 23.8-41.2 \%$ and $29.2-39.5 \%$ to $30.1-41.0 \%, 29.2-$ $40.2 \%$ and $32.6-37.1 \%$; and then reduced to $10.9-34.0 \%$, $14.0-33.4 \%$, and $10.7-28.5 \%$, respectively (Fig. 6). The corresponding $\mathrm{N}_{2} \mathrm{O}$ fluxes increased initially and then were reduced with the peak values of $98.5,68.6,39.7$, and $49.0 \mu \mathrm{g} \mathrm{N}_{2} \mathrm{O} \mathrm{m}^{-2} \mathrm{~h}^{-1}$ observed at $119-239 \mathrm{~h}$ when the WFPS in the top $0-2 \mathrm{~cm}$ soils fall within the ranges of $29-35 \%$, $28-38 \%, 28-39 \%$, and $29-37 \%$ for SW, SUW12, SUW15, and SUW18 soils, respectively. Similarly, the soil drying process incurred substantial $\mathrm{N}_{2} \mathrm{O}$ emissions from all treatments of sandy loam, and the pulse emissions of $\mathrm{N}_{2} \mathrm{O}$ were usually observed in a short period after rewatering.

For sandy loam, $\mathrm{N}_{2} \mathrm{O}$ fluxes after the first watering were significantly correlated to the WFPS in the top 4-8 cm (SW), 4-12 cm (SUW12), 8-12 cm (SUW15), and $8-12 \mathrm{~cm}$ ( $\mathrm{SUW} 18)$ soils $(\mathrm{P} \leq 0.05)$, whereas $\mathrm{N}_{2} \mathrm{O}$ fluxes after the second wetting were highly significantly correlated 
Table 2. Correlations between $\mathrm{N}_{2} \mathrm{O}$ emissions and WFPS of different soils after two waterings under different treatments.

\begin{tabular}{|c|c|c|c|c|c|c|c|c|c|c|}
\hline \multirow{2}{*}{ Texture } & \multirow{2}{*}{$\begin{array}{l}\text { Observation } \\
\text { stage }\end{array}$} & \multirow{2}{*}{\multicolumn{2}{|c|}{ Treatments }} & \multicolumn{7}{|c|}{ Correlations } \\
\hline & & & & 0 & 4 & 8 & 12 & 16 & 20 & 24 \\
\hline \multirow{8}{*}{$\begin{array}{l}\text { Silty } \\
\text { clay }\end{array}$} & \multirow{4}{*}{ After first watering } & SW & \multirow{4}{*}{$\mathrm{n}=9$} & $0.82 * *$ & $0.86^{* *}$ & $0.89 * *$ & $0.80 * *$ & 0.44 & 0.43 & 0.45 \\
\hline & & SUW 12 & & 0.61 & 0.55 & $0.69 *$ & $0.72 *$ & 0.43 & 0.42 & 0.41 \\
\hline & & SUW 15 & & 0.58 & $0.67^{*}$ & 0.51 & $0.71 *$ & 0.44 & 0.39 & 0.38 \\
\hline & & SUW 18 & & 0.56 & 0.62 & $0.67 *$ & $0.69 *$ & 0.40 & 0.38 & 0.36 \\
\hline & \multirow{4}{*}{ After second watering } & SW & \multirow{4}{*}{$\mathrm{n}=6$} & $0.89^{*}$ & $0.91 *$ & $0.88^{*}$ & 0.78 & 0.5 & 0.54 & 0.34 \\
\hline & & SUW 12 & & 0.75 & 0.78 & $0.85^{*}$ & $0.83 *$ & $0.82 *$ & 0.47 & 0.45 \\
\hline & & SUW 15 & & 0.72 & 0.71 & $0.82 *$ & $0.84 *$ & 0.50 & 0.46 & 0.43 \\
\hline & & SUW 18 & & 0.69 & $0.82 *$ & $0.82 *$ & $0.83 *$ & 0.64 & 0.54 & 0.52 \\
\hline \multirow{8}{*}{$\begin{array}{l}\text { Sandy } \\
\text { loam }\end{array}$} & \multirow{4}{*}{ After first watering } & SW & \multirow{4}{*}{$\mathrm{n}=7$} & 0.66 & $0.78^{*}$ & $0.76^{*}$ & 0.62 & 0.42 & 0.26 & 0.3 \\
\hline & & SUW 12 & & 0.71 & $0.76^{*}$ & 0.65 & $0.77 *$ & 0.48 & 0.38 & 0.51 \\
\hline & & SUW 15 & & $0.78 *$ & 0.67 & $0.81^{*}$ & $0.82 *$ & 0.45 & 0.67 & 0.34 \\
\hline & & SUW 18 & & 0.67 & 0.73 & $0.76^{*}$ & $0.76^{*}$ & 0.55 & 0.49 & 0.53 \\
\hline & \multirow{4}{*}{ After second watering } & SW & \multirow{4}{*}{$\mathrm{n}=6$} & $0.93 * *$ & $0.94 * *$ & $0.85^{*}$ & $0.86^{*}$ & 0.60 & 0.47 & 0.44 \\
\hline & & SUW 12 & & 0.66 & 0.67 & 0.78 & $0.83 *$ & 0.42 & 0.37 & 0.36 \\
\hline & & SUW 15 & & 0.73 & 0.79 & $0.81^{*}$ & 0.57 & 0.58 & 0.47 & 0.34 \\
\hline & & SUW 18 & & 0.60 & 0.64 & 0.65 & 0.60 & 0.57 & 0.57 & 0.66 \\
\hline
\end{tabular}

$*$ and $* *$ mean the correlations are significant (at $\mathrm{p} \leq 5 \%$ ) and highly significant (at $\mathrm{p} \leq 1 \%$ ).

to the WFPS in the top $0-4 \mathrm{~cm}$ (SW) soils $(\mathrm{p}<0.01$ ), and significantly correlated to the WFPS in the top $8-12 \mathrm{~cm}$ (SW), $12 \mathrm{~cm}$ (SUW12), and $8 \mathrm{~cm}$ (SUW15) soils ( $\mathrm{p} \leq 0.05$ )
(Table 2). The most significant correlations were found between $\mathrm{N}_{2} \mathrm{O}$ fluxes and the WFPS at $4 \mathrm{~cm}$ depth in SW soil and $8 \mathrm{~cm}$ depth in SUW12 soil after both waterings

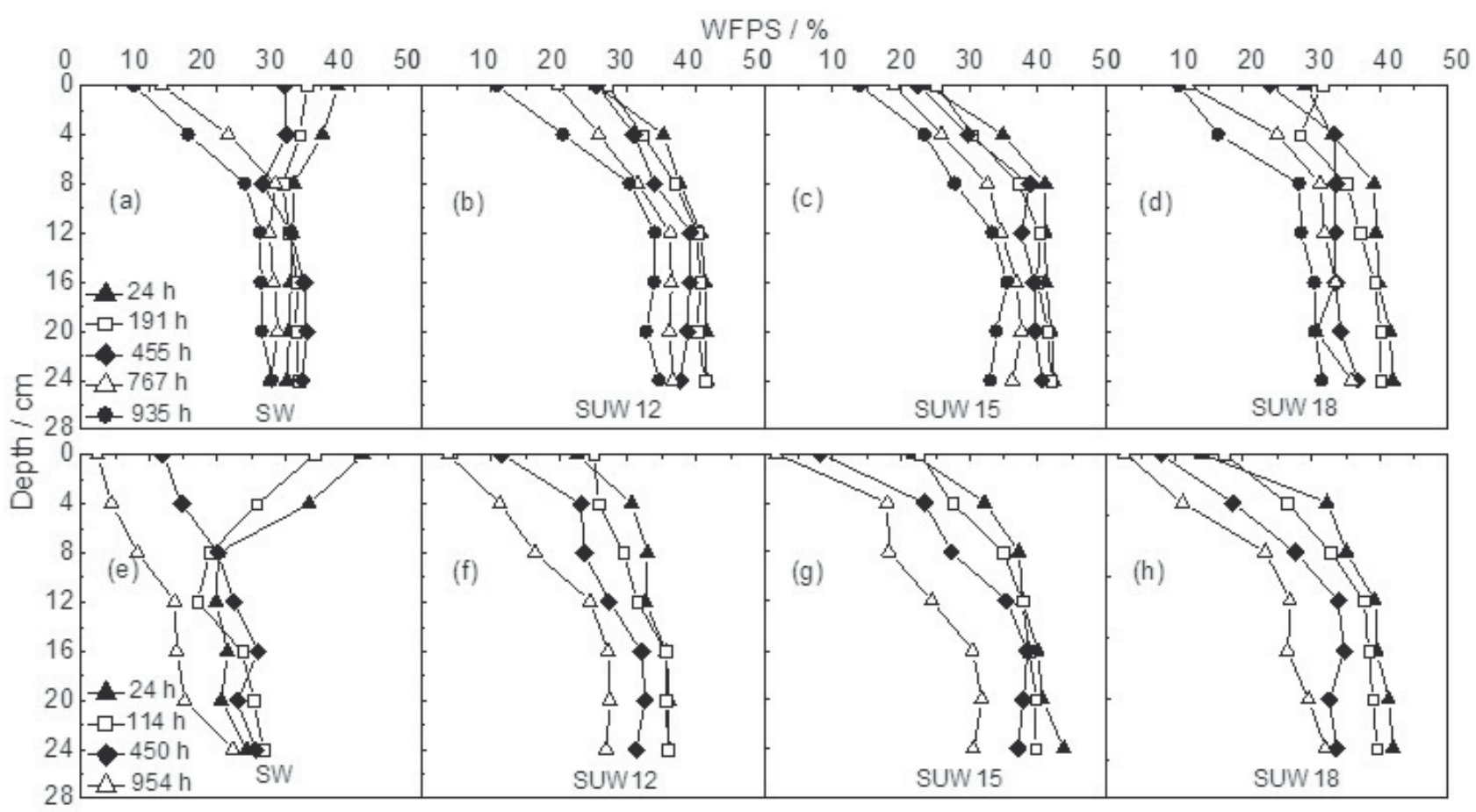

Fig. 6. Vertical soil moisture profiles of sandy loam under different water treatments. 
$(\mathrm{p} \leq 0.05)$, and the WFPS values at 8 and $12 \mathrm{~cm}$ depths in SUW15 and SUW18 soils after the first and second waterings $(p \leq 0.05)$, respectively. As a whole, the WFPS values most significantly correlated to $\mathrm{N}_{2} \mathrm{O}$ fluxes were $10.5-35.5 \%, 24.6-40.8 \%, 24.6-41.2 \%$, and $26.9-39.5 \%$ for SW, SUW12, SUW15, and SUW18 soils, respectively.

\section{Discussions}

The occurrences of short-term peak emissions of $\mathrm{N}_{2} \mathrm{O}$ from both soils during the drying process were confirmed in this experiment (Figs 3 and 4). During the peak $\mathrm{N}_{2} \mathrm{O}$ emission period, the fluxes mainly ranged within 4,305.25,370.2, 1,857.6-4,898.3 $\mu \mathrm{g} \mathrm{N}_{2} \mathrm{O} \mathrm{m}^{-2} \mathrm{~h}^{-1}$, 98.5-126.7, 46.5-98.7 $\mu \mathrm{g} \mathrm{N}_{2} \mathrm{O} \mathrm{m}^{-2} \mathrm{~h}^{-1}$ in SW and SUW treatments for silty clay and sandy loam, respectively. According to the literature [17, 19, 23, 29-31], peak $\mathrm{N}_{2} \mathrm{O}$ fluxes from soils significantly vary from a few to more than $50,000 \mu \mathrm{g} \mathrm{N} \mathrm{N}_{2} \mathrm{O}$ $\mathrm{m}^{-2} \mathrm{~h}^{-1}$, but most of the peak $\mathrm{N}_{2} \mathrm{O}$ fluxes are lower than $10,000 \mu \mathrm{g} \mathrm{N}_{2} \mathrm{O} \mathrm{m}^{-2} \mathrm{~h}^{-1}$, with only a few peak fluxes higher than $15,000 \mu \mathrm{g} \mathrm{N}_{2} \mathrm{O} \mathrm{m}^{-2} \mathrm{~h}^{-1}$. In this study, peak $\mathrm{N}_{2} \mathrm{O}$ fluxes agreed well with most of those previously reported.

Furthermore, the cumulative $\mathrm{N}_{2} \mathrm{O}$ fluxes were lower from SUW soils than from SW soil, with the cumulative fluxes from SUW18 soils as the least. This might ascribe to the uniform distribution of soil moisture and the large scope of surface wetting body in SW soil, which was sufficient enough to add available carbon and even nitrogen to promote soil microbial activities and respiration processes responsible for greenhouse gases emissions [32]. While the surface moisture scope is narrower in SUW soils than SW soil, which may lead to limited substrate motility and result in reduced $\mathrm{N}_{2} \mathrm{O}$ emissions, both of the above reasons may account for the lower $\mathrm{N}_{2} \mathrm{O}$ cumulative emissions under SUW treatments.

In addition, the WFPS values in the top $0-12 \mathrm{~cm}$ soils influenced $\mathrm{N}_{2} \mathrm{O}$ fluxes significantly from SW and SUW soils, which were in agreement with earlier studies [8, 33]. Moreover, it has been reported that peak $\mathrm{N}_{2} \mathrm{O}$ emissions were observed when the WFPS fell within the range of $60 \%$ to $70 \%$ [34-35], $45 \%$ to $75 \%$ [11-12], $60 \%$ to $80 \%$ [26], or $75 \%$ to $86 \%[10,13]$. In this research, the WFPS values in the $0-12 \mathrm{~cm}$ soils corresponding to the peak $\mathrm{N}_{2} \mathrm{O}$ fluxes in SW and SUW soils from silty clay and sandy loam were $34-66 \%, 22-72 \%, 25-35 \%$, and $19-39 \%$, respectively. The ranges of soil moisture corresponding to $\mathrm{N}_{2} \mathrm{O}$ peak fluxes from silty clay were greater than those of sandy loam. This is possibly because silty clay has a stronger water retention capacity, and the soil moisture varies slowly, thus resulting in the higher soil moisture level for peak $\mathrm{N}_{2} \mathrm{O}$ fluxes from silty clay [36]. Simultaneously, the current result was somewhat different from the previously reported optimal soil moisture range (45-75\% WFPS) for peak $\mathrm{N}_{2} \mathrm{O}$ emissions. The reasons for this phenomenon may be that the production process of $\mathrm{N}_{2} \mathrm{O}$ emissions was complicated and its formation were simultaneously affected by multiple factors, such as soil texture, meteorological factors, soil microorganisms, and soil nitrogen sources [12, 17, 23, 37]. Moreover, some peaks of $\mathrm{N}_{2} \mathrm{O}$ appeared following rainfall events. For example, a peak $\mathrm{N}_{2} \mathrm{O}$ flux of 2,001.6 $\mu \mathrm{g} \mathrm{N}_{2} \mathrm{O} \mathrm{m} \mathrm{m}^{-2} \mathrm{~h}^{-1}$ for SW treatment from silty clay were observed $24 \mathrm{~h}$ after a $6.3 \mathrm{~mm}$ rainfall (Fig. 3), and the peak emissions of 24.07-68.29 $\mu \mathrm{g} \mathrm{N}_{2} \mathrm{O} \mathrm{m}^{-2} \mathrm{~h}^{-1}$ for SW and SUW treatments from sandy loam occurred in the process of a heavy rain (Fig. 4). Assuming that the soil mesocosms were stored under a rain shelter, this implies that the soil nitrification and denitrification process in surface soil might respond to the high air humidity after rainfall events.

In addition, the magnitude of $\mathrm{N}_{2} \mathrm{O}$ fluxes is closely related to soil texture $[12,14]$. Heavy-textured soils frequently produce higher $\mathrm{N}_{2} \mathrm{O}$ fluxes than light soils [38]. The $\mathrm{N}_{2} \mathrm{O}$ fluxes from fine-textured soils were significantly higher than those from coarse-textured soils [39-42]. In this research, $\mathrm{N}_{2} \mathrm{O}$ fluxes in all treatments from silty clay were significantly higher than those from sandy loam. As reported by [43], clay soils resulted in higher $\mathrm{N}_{2} \mathrm{O}$ fluxes than sandy or loam soils. Total $\mathrm{N}$ content in silty clay is $1.4 \mathrm{~g} \mathrm{~kg}^{-1}$ - much higher than the $\mathrm{N}$ content in sandy loam $\left(0.4 \mathrm{~g} \mathrm{~kg}^{-1}\right)$. Both the differences in soil texture and soil nitrogen content levels might account for the differences in the magnitude of $\mathrm{N}_{2} \mathrm{O}$ fluxes between the two soils.

Moreover, the peaks of $\mathrm{N}_{2} \mathrm{O}$ after the second watering appeared earlier than those after the first, although the $\mathrm{N}_{2} \mathrm{O}$ emissions from all treatments after the second watering varied in a similar way to those observed after the first watering, which was ascribed to the high temperature and the rapid change rate in soil moisture after the second watering [10]. Additionally, $\mathrm{N}_{2} \mathrm{O}$ fluxes from silty clay with both SW and SUW treatments were reduced significantly after the second watering when compared with those after the first watering, but for sandy loam it was the opposite. The major reasons for this difference may be that sandy loam has more larger particles, stronger permeability, and poor water retention capacity, and its soil moisture is easily influenced by air temperature [7, 44], which may result in higher $\mathrm{N}_{2} \mathrm{O}$ pulse emissions from sandy loam in high temperature conditions after the second watering than after the first. At the same time, silty clay has a weak soil organic matter holding facility and can provide more substrate for microorganisms, that also partially contributes to higher $\mathrm{N}_{2} \mathrm{O}$ pulse emissions after the second watering $[42,45]$. But for the silty clay, the reduced $\mathrm{N}_{2} \mathrm{O}$ pulse emissions after the second watering when compared with the first may be attributed to the restrictions of carbon for microorganisms after the high pulse emission following the first.

The current experiment showed that the vertical nonuniform soil moisture distribution patterns resulting from subsurface wetting resulted in reduced $\mathrm{N}_{2} \mathrm{O}$ fluxes from SUW soils (for both silty clay and sandy loam) when compared with those from SW soil. Partial wetting irrigation techniques such as drip irrigation, subsurface drip irrigation, and seepage irrigation (which are applied widely to cope with water scarcity) are characterized as irrigation techniques with non-uniform soil-wetting patterns $[17,46]$. This may be helpful to reduce $\mathrm{N}_{2} \mathrm{O}$ 
emissions from irrigated farmland. There might be an ideal or optimal soil-wetting pattern that can improve water use efficiency and reduce $\mathrm{N}_{2} \mathrm{O}$ emissions for soil under partial wetting irrigation. The non-uniform soil moisture vertical distribution also existed in the hydro-fluctuation belt as a result of the frequent variation in shallow groundwater levels. In the soil in the hydro-fluctuation belt, the soil moisture distribution may be one of the most important factors that affect $\mathrm{N}_{2} \mathrm{O}$ emissions. A recent study conducted in the hydro-fluctuation belt of the Three Gorge Reservoir confirmed this conclusion by finding that the water level had a significant impact on $\mathrm{N}_{2} \mathrm{O}$ emissions [47]. Therefore, fluxes of $\mathrm{N}_{2} \mathrm{O}$ from different soils must be examined under more partial wetting patterns to reveal the influence of soil-wetting patterns on soil $\mathrm{N}_{2} \mathrm{O}$ emissions and figure out an ideal soil-wetting pattern. The current research was conducted on soil without plants and fertilizers. Since plant growth and fertilization management are important factors linked to soil $\mathrm{N}_{2} \mathrm{O}$ emissions $[12,48]$, the influence of a non-uniform soil-wetting pattern on $\mathrm{N}_{2} \mathrm{O}$ emissions should be addressed under conditions with plant growth and fertilization management, and also further explore the best way to realize the ideal soil-wetting pattern.

\section{Conclusions}

Soil moisture is a key factor affecting soil $\mathrm{N}_{2} \mathrm{O}$ fluxes, and different vertical watering patterns resulted in significant variations in soil $\mathrm{N}_{2} \mathrm{O}$ emissions. Short-term peak emissions of $\mathrm{N}_{2} \mathrm{O}$ during the drying process from both soils were observed. The increased air permeability and gas diffusivity in soils might account for the high pulse $\mathrm{N}_{2} \mathrm{O}$ emissions caused by moisture variation. $\mathrm{N}_{2} \mathrm{O}$ emissions from soils in both SW and SUW treatments increased with soil drying and peaked when the WFPS fell within the ranges of $34-66 \%, 22-72 \%, 25-35 \%$, and $19-39 \%$ for silty clay and sandy loam, respectively, even though the surface soil moistures in these treatments were somewhat different from the previously reported optimal soil moisture range (45-75\% WFPS) for peak $\mathrm{N}_{2} \mathrm{O}$ emissions. Generally, the cumulative $\mathrm{N}_{2} \mathrm{O}$ emission fluxes were lower from SUW than SW soils, with the cumulative fluxes from SUW18 as the least. $\mathrm{N}_{2} \mathrm{O}$ emissions were more easily influenced by soil moisture in SW soils than in SUW soils, and fluxes of $\mathrm{N}_{2} \mathrm{O}$ were more closely related to the WFPS of 0-12 cm soils in SW soil than in SUW soils. Our results also suggest that the $\mathrm{N}_{2} \mathrm{O}$ flux from soil of silty clay with higher $\mathrm{N}$ content is much higher than that from sandy loam. However, more research is needed to identify an ideal soil-wetting pattern and the best way to realize it, especially on soil with plant growth and fertilization.

\section{Acknowledgements}

This research was financially supported by the National Natural Science Foundation of China (Nos. 51179051 and 51209066) and the Advanced Science and Technology
Innovation Team in Colleges and Universities in Jiangsu Province.

\section{References}

1. IPCC. In: Metz B., Davidson OR8, Bosch PR(eds) Climate change 2007: mitigation, constribution of Working Group III to the fourth assessment report of the intergovern-mental panel on climate change. Cambridge University Press, Cambridge. 2007.

2. BESSOU C., MARY B., LEONARD J., ROUSSEL M., GREHAN E., GABRIELLE B. Modelling soil compaction impacts on nitrous oxide emissions in arable fields. Eur. J. Soil. Sci 61, 348, 2010.

3. XIA Y., LI Y, LI X., GUO M., SHE D., YAN X. Diurnal pattern in nitrous oxide emissions from a sewage-enriched river. Chemosphere 92, 421, 2013.

4. SYP A., FABER A., BORZECKA-WALKER M., OSUCH D. Assessment of Greenhouse Gas Emissions Winter Wheat Farms Using Data Envelopment Analysis Approach. Pol. J. Environ. Stud 24, 2197, 2015.

5. FAO. World Agricultural Towards 2015/2030: an FAO Perspetive. FAO, Rome. 2003.

6. HADI A., INUBUSHI K., YAGI K. Effect of water management on greenhouse gas emissions and microbial properties of paddy soils in Japan and Indonesia. Paddy Water Environ 8, 319, 2010.

7. JIAO Z.H., HOU A.X., SHI Y., HUANG G.H., WANG Y.H., CHEN X. Water management influencing methane and nitrous oxide emissions from rice field in relation to soil redox and microbial community. Commun. Soil. Sci. Plant. Anal 37, 1889, 2003.

8. DING L. Preliminary Study of Processes of Nitrous Oxide Emission from Soil and Plant in the Northest Farmland [dissertation]. Jilin Agricultural University. 2008.

9. YAO Z.S., ZHOU Z.X., ZHENG X.H., XIE B.H., MEI B.L., WANG R., BUTTERBACH-BAHL K., ZHU J.G. Effects of organic matter incorporation on nitrous oxide emissions from rice-wheat rotation ecosystems in China. Plant Soil 327, 315, 2010.

10. PENG S.Z., HOU H.J., XU J.Z., YANG S.H., MAO Z. Lasting effects of controlled irrigation during rice-growing season on nitrous oxide emissions from winter wheat croplands in Southeast China. Paddy. Water. Environ 11, $583,2012$.

11. HANSEN S., MAEHLUM J.E., BAKKEN L.R. $\mathrm{N}_{2} \mathrm{O}$ and $\mathrm{CH}_{4}$ fluxes in soil influenced by fertilization and tractor traffic. Soil. Biol. Biochem 25, 621, 1993.

12. KHALIL M.I., BAGGS E.M. $\mathrm{CH}_{4}$ oxidation and $\mathrm{N}_{2} \mathrm{O}$ emissions at varied soil water-filled pore spaces and headspace $\mathrm{CH}_{4}$ concentrations. Soil. Biol. Biochem 37, 1785, 2005.

13. SEY B.K., MANCEUR A.M., WHALEN J.K., GREORICH E.G., ROCHETTE P. Small-scale heterogeneity in carbon dioxide, nitrous oxide and methane production from aggregates of a cultivated sandy-loam soil. Soil. Biol. Biochem 40, 2468, 2008.

14. DING W.X., CAI Y., CAI Z.C, YAGI K., ZHENG X.H. Nitrous oxide emissions from an intensively cultivated maize-wheat rotation soil in the North China Plain. Sci. Total. Environ 373, 501, 2007.

15. BARTON L., SCHIPPER L.A. Nitrous oxide emissions from soils irrigated with dairy farm effluent. J. Environ. Qual 30, 1881, 2001. 
16. HUANG J., LIU H., WANG B. $\mathrm{CO}_{2}$ and $\mathrm{N}_{2} \mathrm{O}$ Emission from Red Soil Dry-land under Long-term Fertilization. Chin. Agr. Sci. Bull 25, 428, 2009.

17. KALLENBACH C., ROLSTON D.E., HORWATH W.R. Cover cropping affects soil $\mathrm{N}_{2} \mathrm{O}$ and $\mathrm{CO}_{2}$ emissions differently depending on type of irrigation. Agr. Ecosyst. Environ 137, 251, 2010.

18. DENG J., ZHOU Z.X, ZHENG X.H, LIU C.Y., YAO Z.S., XIE B.H., CUI F., HAN S.H., ZHU J.G.. Annual emissions of nitrous oxide and nitric oxide from rice-wheat rotation and vegetable fields: a case study in the Tai-Lake region, China. Plant Soil 360, 37, 2012.

19. NAGATA O., YAZA T., YOSUKE Y. Nitrous oxide emissions from drained and mineral soil-dressed peatland in central Hokkaido, Japan. J. Agr. Meteorol 66, 23, 2010.

20. SCHEER C., WASSMANN R., KLENZLER K., LBRAGIMOV N., ESCHANOV R. Nitrous oxide emissions from fertilized, irrigated cotton (Gossypium hirsutum L.) in the Aral Sea Basin, Uzbekistan: Influence of nitrogen applications and irrigation practices. Soil. Biol. Biochem. 40, 290, 2008.

21. XU J.Z., WEI Q., YANG S.H, WANG Y.H, LV Y.P. Diurnal pattern of nitrous oxide emissions from soils under different vertical moisture distribution conditions. Chilean. J. Agric. Res 76, 84, 2016.

22. BEARE M.H., GREGORICH E.G., ST-GEORGES P. Compaction effects on $\mathrm{CO}_{2}$ and $\mathrm{N}_{2} \mathrm{O}$ production during drying and rewetting of soil. Soil. Biol. Biochem, 41, 611, 2009.

23. YAMAMOTO A., AKIYAMA H., NAOKAWA T., YAGI K. Effect of lime-nitrogen application on $\mathrm{N}_{2} \mathrm{O}$ emission from an Andosol vegetable field. Soil. Sci. Plant. Nutr 58, 245, 2012.

24. ZHONG Z.X., LI Y.E., HUA L., WAN Y.Y., JIANG N.N. Effects of different fertilizer levels on $\mathrm{N}_{2} \mathrm{O}$ flux from protected vegetable land (in Chinese with English abstract). Transactions of the CSAE 26, 269, 2010.

25. REPO M.E., Susiluoto S., LIND S.E., JOKINEN S., ELSAKOV V., BIAS C., VIRTANEN T., MARTIKAINEN P.J. Large $\mathrm{N}_{2} \mathrm{O}$ emissions from cryoturbated peat soil in tundra. Nature Geosci 2, 189, 2009.

26. DOBBIE K.E., SMITH K.A. The effects of temperature, water-lled pore space and land use on $\mathrm{N}_{2} \mathrm{O}$ emissions from an imperfectly drained gleysol. Eur. J. Soil. Sci 52, 667, 2001.

27. MKHABELA M.S, GORDON R., BURTON D., MADANI A., HART W., ELMI A. Ammonia and nitrous oxide emissions from two acidic soils of Nova Scotia fertilised with liquid hog manure mixed with or without dicyandiamide. Chemosphere 65, 1381, 2006.

28. ZHANG H.H., HE P.J., SHAO L.M. Ammonia volatilization, $\mathrm{N}$ Ammonia volatilization, $\mathrm{N}_{2} \mathrm{O}$ and $\mathrm{CO}_{2}$ emissions from landfill leachate-irrigated soils. Waste. Manage 30, 119, 2010.

29. JIA J., SUN L., KONG X., YAN X., Xiong Z. Annual $\mathrm{N}_{2} \mathrm{O}$ and $\mathrm{CH}_{4}$ emissions from intensively managed vegetable fields in Nanjing, China. Soil. Sci. Plant. Nutr 58, 91, 2012.

30. TOMA Y., TAKAKAI F., DARUNG U., KURAMOCHI K., LIMIN S.H., DOHONG S., HATANO R. Nitrous oxide emission derived from soil organic matter decomposition from tropical agricultural peat soil in central Kalimantan, Indonesia. Soil. Sci. Plant. Nutr 57, 436, 2011.
31. HOU H.J., PENG S.Z., XU J.Z., YANG S.H., MAO Z. Seasonal variations of $\mathrm{CH}_{4}$ and $\mathrm{N}_{2} \mathrm{O}$ emissions in response to water management of paddy fields located in Southeast China. Chemosphere 89, 884, 2012.

32. VARGAS V.P., CANTARELLA H., MARTINS A.A., SOARES J.R., DOCARMO J.B., DEANDRADE C.A. Sugarcane Crop Residue Increases $\mathrm{N}_{2} \mathrm{O}$ and $\mathrm{CO}_{2}$ Emissions Under High Soil Moisture Conditions. Sugar. Tech 16, 174, 2014.

33. CONARD R., SEILER W., BUNSE G. Factors influencing the loss of fertilizer nitrogen into the atmosphere as N2O. J. Geophys. Res 88, 6709, 1983.

34. BOUMAN A.F. Nitrogen oxides and tropical agriculture. Nature, 392, 866, 1998.

35. BATEMAN E.J., BAGGS E.M. Contributions of nitrification and denitrification to $\mathrm{N}_{2} \mathrm{O}$ emissions from soils at different water-filled pore space. Biol. Fert. Soils 41, 379, 2005.

36. LI Y.H., WANG F., LIU R.L., ZHAO T.C., CHEN C., YANG Z.L. Study on $\mathrm{N}_{2} \mathrm{O}$ Emission in the Farmland Ecosystem of Arid Areas. J. Anhui. Agr. Sci 36, 15197, 15265, 2008.

37. PFAB H., PALMER I., BUEGGER F., FIEDLER S., MULLER T., RUSER R. Influence of a nitrification inhibitor and of placed $\mathrm{N}$-fertilization on $\mathrm{N}_{2} \mathrm{O}$ fluxes from a vegetable cropped loamy soil. Agr. Ecosyst. Environ 150, 91, 2012.

38. SKIBA U., SMITH K.A., FOWLER D. Nitriftcation and denitrification as sources of nitric oxide and nitrousoxide in a sandy loam soil. Soil. Biol. Biochem 25, 1527, 1992.

39. PATHAK H. Emissions of nitrous oxide from soil. Curr. Sci 77, 359, 1999.

40. PALM C.A., ALEGRE J.C., AREVALO L., MUTUO P.K., MOSIER A.R., COE R. Nitrous oxide and methane fluxes in six different land use systems in the Peruvian Amazon. Global. Biogeochem. Cy 16, 21-1-21-13, 2002.

41. WLODARCZYK T., STEPNIEWSKI W., BRZEZINSKA M., ZOFIA S. Nitrate stability in loess soils under anaerobic conditions-laboratory studies. J. Plant. Nutr. Soil. Sci 167, 693, 2004.

42. HARRISON-KIRKA T., BEARE M.H., MEENKEN E.D., CONDRON L.M. Soil organic matter and texture affect responses to dry/wet cycles: Effects on carbon dioxide and nitrous oxide emissions. Soil. Biol. Biochem 57, 43, 2013.

43. DING H., CAI G.X. WANG Y.S., CHEN D. Nitrification and Denitrification Potential in Different Types of Soils in the North China Plain. Agr. Environ. Protect 20, 390, 2001.

44. LU F. The research of farmland $\mathrm{N}_{2} \mathrm{O}$ emission mechanism and its influence factors. J Green sci Tech, 10, 169, 2013.

45. ARAH J.R.M., SMITH K.A., CRICHTON I.J., LI H.S. Nitrous oxide production and denitrification in Scottish arable soils. J.Soil. Sci, 42, 351, 1991.

46. WANG C., LI Y.N. Experimental Research on Soil Wetting Front Infiltration of Subsurface Drip Irrigation. China. Rural. Water. Hydropower 3, 38, 2011.

47. WU Y.Y. Study on Greenhouse Gas Flux from Newly Created Marshes and Carbon Sink in the Three Gorges Reservoir [Master's dissertation]. Chongqing University. 2012.

48. MC TAGGART I.P., AKIYAMA H., TSURUTA H., BALL B.C. Influence of soil physical properties, fertiliser type and moisture tension on $\mathrm{N}_{2} \mathrm{O}$ and $\mathrm{NO}$ emissions from nearly saturated Japanese upland soils. Nutr. Cycl. Agroecosys, 63, 207, 2002. 